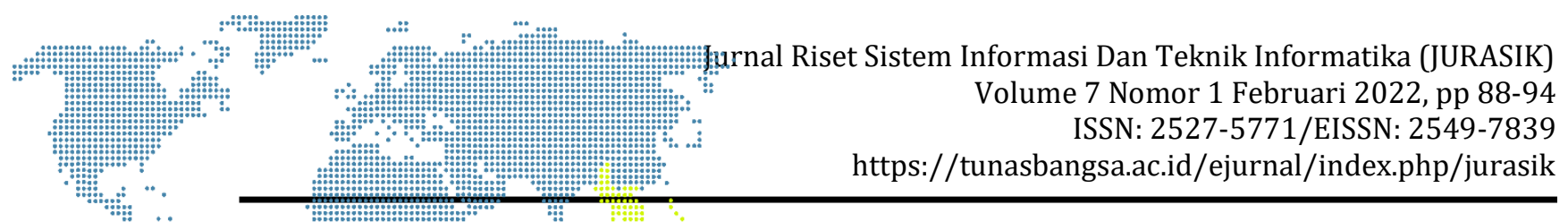

\title{
Aplikasi Pengolahan Citra Digital Menentukan Bobot Sapi Dengan Metode Titik Berat Berbasis Android
}

\author{
Vicki Yuda Mahendra' ${ }^{1}$, Aditya Akbar Riadi ${ }^{2}$ Evanita $^{3}$ \\ ${ }^{1,2,3}$ Program Studi Teknik Informatika, Fakultas Teknik, Universitas Muria Kudus \\ Email :1201751195@std.umk.ac.id, ²aditya.akbar@umk.ac.id, ${ }^{3}$ evanita@umk.ac.id
}

\begin{abstract}
Cattle is a consumption animal that is in great demand by Indonesians, its soft meat and delicious taste make beef one of the most expensive meats at the moment, cattle breeders are now starting to modernize and continue to develop their farms to make it easier to maintain and sell cattle, in this modern era there are many things that are facilitated by technology that makes it easier for people to do things, one of which is calculating the weight of a cow with an android application by entering an image of a cow that will be processed and will produce a value for the size and weight of the cow. The weight of the cow can be calculated using the Schoorl formula and the Modified/ Lambourne formula which requires variables of body length and chest circumference for calculation. To get body weight, it is necessary to measure chest circumference and body length which are measured manually. However, the reality in the field shows that to get the values for chest circumference and body length, manual measurements need to be carried out, and this is not easy to do because cows are difficult to condition. In the field itself, there is no practical and accurate tool to calculate chest circumference, body length and weight of cows. Starting from this problem, it gave rise to the idea of making a tool that can measure accurately and easily.
\end{abstract}

Keyword: Cow, Image Processing, Schoorl Formula

\begin{abstract}
Abstrak
Sapi merupakam hewan konsumsi yang sangat diminati orang Indonesia dagingnya yang lembut dan rasanya yang enak membuat sapi menjadi salah satu daging termahal pada saat ini, peternak sapi sekarang sudah mulai modern dan terus mengembangkan peternakanya agar lebih memudahkan pemeliharaan maupun penjualan sapi, di jaman modern ini banyak hal yang dimudahkan dengan teknologi yang membuat orang-orang dapat lebih mudah melakukan sesuatu, salah satunya adalah penghitungan bobot sapi dengan aplikasi android dengan memasukan gambar sapi yang akan di proses dan akan menghasilkan nilai ukuran dan bobot sapi. Berat sapi dapat ditentukan dengan menggunakan persamaan Schoorl dan resep Modifikasi/ Lambourne yang membutuhkan faktor panjang tubuh dan keliling dada untuk estimasi. Untuk mendapatkan berat badan, penting untuk mengukur lingkar dada dan panjang badan yang diperkirakan secara fisik. Padahal, fakta di lapangan menunjukkan bahwa untuk mendapatkan kualitas batas dada dan panjang badan, penting untuk mengukur secara fisik, dan ini tidak sulit dilakukan karena sapi sulit dikondisikan. Di lapangan yang sebenarnya, tidak ada alat yang berguna dan tepat untuk memastikan garis dada, panjang tubuh dan berat sapi. Berawal dari permasalahan tersebut, memunculkan kemungkinan untuk dibuatnya suatu alat yang dapat mengukur secara tepat dan efektif.
\end{abstract}

Kata kunci: Sapi, Pengolahan Citra, Rumus Schoorl

\section{PENDAHULUAN}

Peternak merupakan salah satu profesi yang bisa berpeluang mendapat keuntungan besar, banyak yang terjun didunia peternakan untuk mencapai kesuksesan menjadi pengusaha ternak, salah satunya yaitu peternak sapi, ternak sapi ada beberapa jenis yaitu ternak sapi perah dan ternak sapi potong. Ternak 


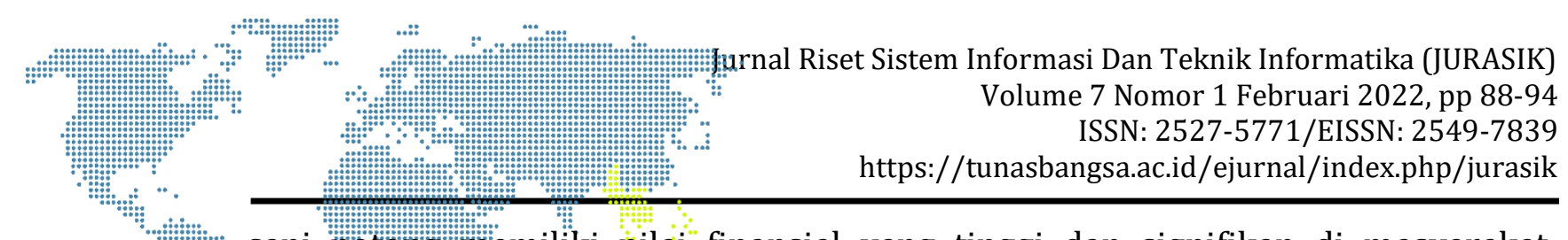

sapi potong memiliki nilai finansial yang tinggi dan signifikan di masyarakat. úmlah pọmutasi sapi (daging sapi dan sapi perah) di Indonesia adalah 15,4 juta ëkor. Perkembangan populasisusapi pedaging selama tahun 2003-2011 mencapai 5,33\% setiap tahun atau meningkat normal 655,5 ribu ekor setiap tahun [1].

Ada beberapa kondisi untuk menghitung beban yang diantisipasi dari sapi, terutama persamaan Schoorl dan resep yang diubah, keduanya mengharapkan informasi untuk dikenali oleh sirkuit dada dan panjang tubuh. Untuk mendapatkan sifat batas dada dan panjang badan, penting untuk mengukur secara nyata, namun di lapangan hal itu terjadi begitu saja, hal ini mudah dilakukan mengingat kesulitan sapi untuk membentuk. tetap selama pengukur. Untuk itu kami sangat menginginkan suatu cara dan alat yang dapat mengukur batas dada dan panjang badan secara normal. Kenyataan di lapangan menunjukkan bahwa tidak ada perangkat yang membumi dan pasti untuk memastikan batas dada, panjang badan dan berat badan sapi perah. Berawal dari masalah tersebut, muncul pemikiran untuk membuat alat untuk memastikan berat sapi dengan cara yang bermanfaat dan pas.

Dalam penilitian ini bertujuan untuk membuat sebuah sistem pengolahan citra digital menggunakan perangkat android untuk menentukan bobot sapi secara mudah dengan menggunakan algoritma deteksi tepi canny untuk menentukan ukuran lingkar dada dan panjang pada tubuh sapi yang nantinya akan di hitung menggunakan rumus schrool untuk menentukan bobot sapi tersebut. Sistem pengolahan citra digital untuk menetukan bobot sapi ini nantinya akan mempermudah penjual ataupun pembeli yang akan menghitung bobot sapi dengan mudah dan praktis.

\section{METODOLOGI PENELITIAN}

\subsection{Tahap Persiapan}

Pada tahapan ini persiapan yang dilakukan adalah sebagai berikut:

a. Menentukan kebutuhan data yang digunakan, Data mengenai rumus menghitung bobot sapi dan apa saja yang dibutuhkan untuk menentukan bobot sapi.

b. Mengumpulkan data yang dibutuhkan, data yang sudah ditentukan di atas selanjutnya dikumpulkan untuk diproses.

c. Mempersiapkan alat dan bahan penelitian, Yang dimaksud alat disini adalah perangkat yang digunakan untuk membuat sebuah aplikasi android, sedangkan bahan adalah data-data yang telah dikumpulkan, untuk selanjutnya diolah ke dalam program.

\subsection{Pengumpulan Data}

Pengumpulan data dilakukan untuk memperoleh informasi yang dibutuhkan dalam mencapai tujuan penelitian. Adapun metode pengumpulan data tersebut antara lain:

a) Observasi

Penulis mendatangi obyek yang diteliti secara langsung dengan tujuan untuk melakukan observasi dan melakukan pengamatan mengenai bobot sapi. 


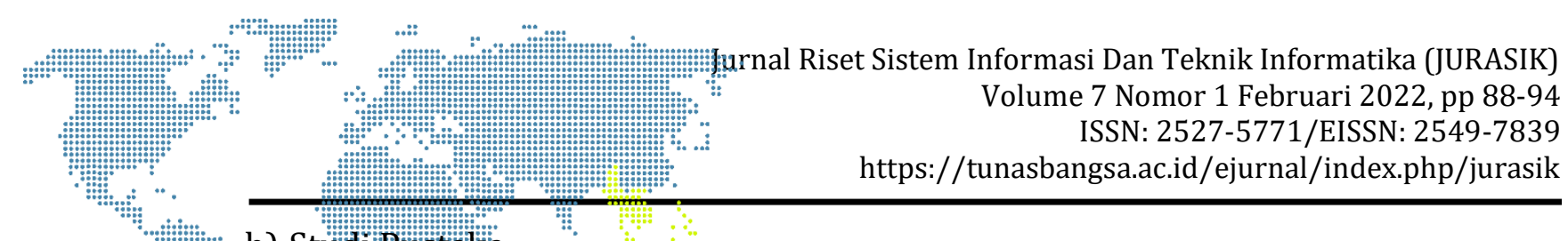

b) Stüdi Puistaka

Studi puistaka dilakukan dêngan cara mengumpulkan data dan informasi dari membaca dan mempelajarr buku-buku, referensi serta situs-situs penyedia layanan yang berhubungan dengan perhitungan bobot sapi menggunakan metode titik berat.

\subsection{Pengembangan Perangkat Lunak / Komputasi}

Dalam pengembangan perangkat lunak pada penelitian ini menggunakan metode waterfall berikut penjelasanya. Perbaikan kerangka umum dibantu melalui beberapa fase/langkah. Teknik peningkatan produk disebut juga Software Development Life Cycle (SDLC) [2-5]. Teknik kaskade adalah strategi pengembangan pemrograman yang paling berpengalaman karena biasa. Strategi Waterfall adalah pendekatan SDLC paling awal yang digunakan untuk kemajuan pemrograman. Pengelompokan dalam Metode Waterfall dilakukan secara berurutan, mulai dari proses persiapan, penyelidikan, perencanaan, dan pelaksanaan pada framework.

Teknik ini dilakukan dengan metodologi yang terencana, dimulai dari tahap kebutuhan kerangka kerja dan kemudian beralih ke tahap pemeriksaan, perencanaan, pengkodean, pengujian/konfirmasi, dan dukungan. Sarana yang dilalui harus diselesaikan sendiri-sendiri (tidak dapat melompat ke tahap berikutnya) dan dijalankan secara berurutan, selanjutnya disebut kaskade, ada lima tahap, tahapannya adalah sebagai berikut [6-8]:

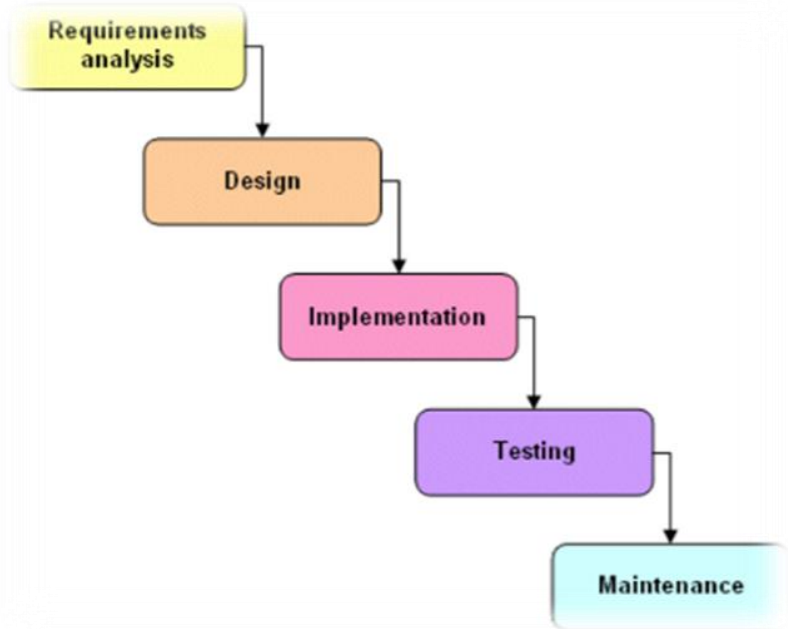

Gambar 1. Metode Waterfall

\section{HASIL DAN PEMBAHASAN}

\subsection{Tampilan Antarmuka}

Berikut ini merupakan tampilan awal aplikasi prediksi bobot sapi berbasis android yang terdiri dari halaman Splash, Halaman Utama, Mulai, Tentang, dan Hasil Perhitungan. 

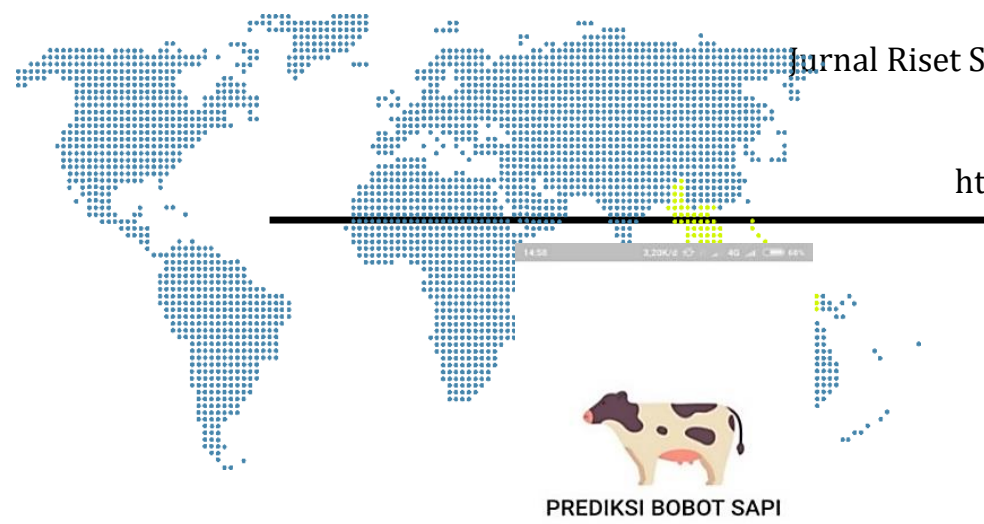

\section{Volume 7 Nomor 1 Februari2022 pp 88-94 \\ ISSN: 2527-5771/EISSN: 2549-7839 \\ https://tunasbangsa.ac.id/ejurnal/index.php/jurasik}

Gambar 2. Halaman Splash

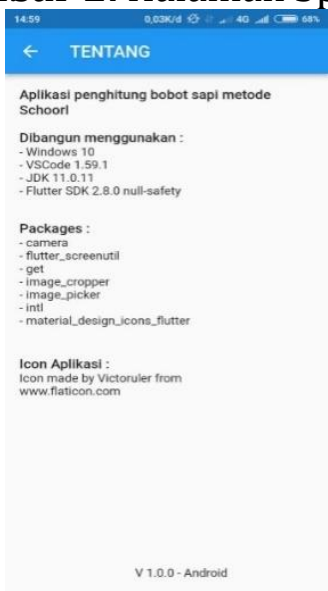

Gambar 4. Halaman Tentang

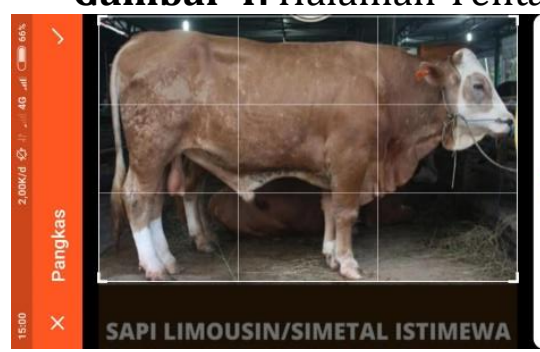

Gambar 6. Halaman Pangkas

Gambar

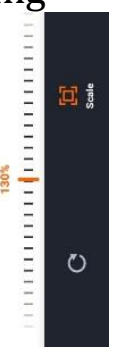

Gambar 5. Halaman Ambil Gambar

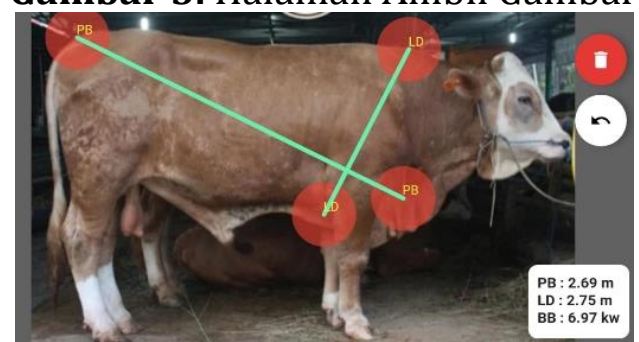

Gambar 7. Halaman Hasil

Perhitungan

Pada gambar 7 merupakan tampilan hasil perhitungan bobot sapi yang memiliki hasil diketahui panjang badan, lingkar dada, dan bobot sapi tersebut.

\subsection{Pengujian Sistem}

Berikut merupakan evaluasi perbandingan bobot sapi sebenarnya dengan bobot sapi hasil dari sistem prediksi bobot sapi dapat di lihat pada tabel 4.1. Aplikasi Pengolahan Citra Penghitung Bobot Sapi dengan Metode Titik Berat Berbabis Android ini menggunakan pengukuran akurasi Mean Absolute Percentage Error (MAPE) dengan cara menghitung seberapa besar persentase 


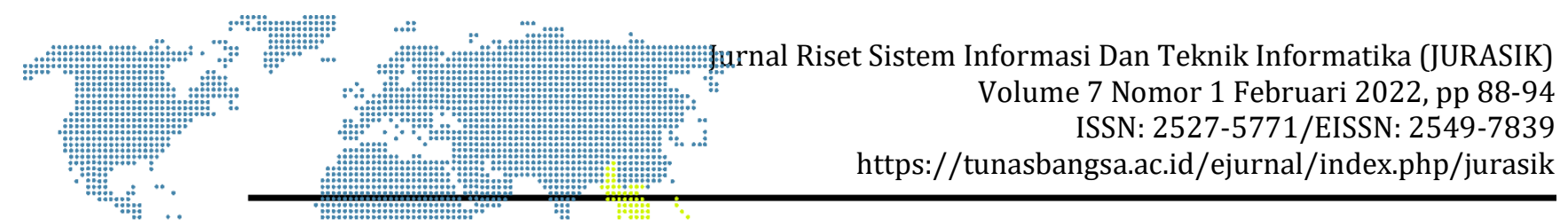

kesalahan siteen aplikasi bobot sapi dengan nilai bobot sapi sebenarnya dengan rumus dibawah ini:



Tabel 1. Perhitungan Akurasi Mape

\begin{tabular}{|c|c|c|c|c|c|c|}
\hline No & Gambar Sapi & $\begin{array}{c}\text { Panjang } \\
\text { Badan }\end{array}$ & $\begin{array}{c}\text { Lingkar } \\
\text { dada }\end{array}$ & $\begin{array}{c}\text { Bobot sapi } \\
\text { sebenarnya }\end{array}$ & $\begin{array}{c}\text { Bobot sapi } \\
\text { Menggunakan } \\
\text { sistem }\end{array}$ & $\begin{array}{c}\text { Persentase } \\
\text { Kesalahan } \\
\text { absolute }\end{array}$ \\
\hline 1 & & $2,16 \mathrm{~m}$ & $2,20 \mathrm{~m}$ & $450 \mathrm{Kg}$ & $446 \mathrm{Kg}$ & $0,89 \%$ \\
\hline 2 & & $2,35 \mathrm{~m}$ & $2,31 \mathrm{~m}$ & $500 \mathrm{Kg}$ & $494 \mathrm{Kg}$ & $1,20 \%$ \\
\hline 3 & & $1,18 \mathrm{~m}$ & $2,11 \mathrm{~m}$ & $415 \mathrm{Kg}$ & $410 \mathrm{Kg}$ & $1,20 \%$ \\
\hline 4 & & $1,66 \mathrm{~m}$ & $1,61 \mathrm{~m}$ & $250 \mathrm{Kg}$ & $240 \mathrm{Kg}$ & $4,00 \%$ \\
\hline 5 & & $2,67 \mathrm{~m}$ & $2,75 \mathrm{~m}$ & $700 \mathrm{Kg}$ & $696 \mathrm{Kg}$ & $0,57 \%$ \\
\hline 6 & & $2,78 \mathrm{~m}$ & $3,44 \mathrm{~m}$ & $1100 \mathrm{Kg}$ & $1090 \mathrm{Kg}$ & $0,91 \%$ \\
\hline
\end{tabular}




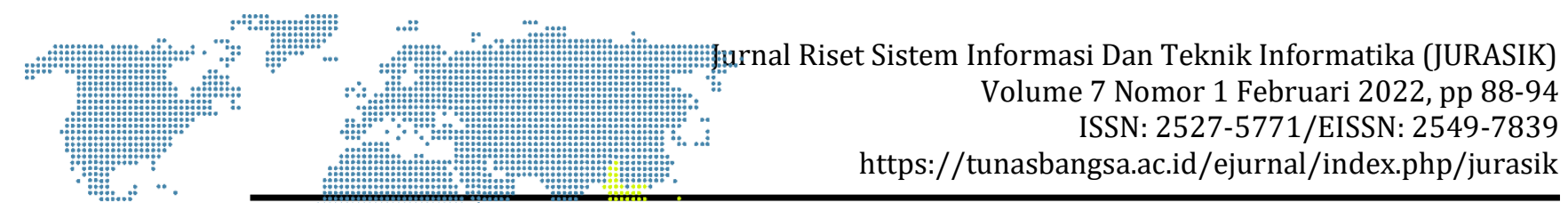

\begin{tabular}{|c|c|c|c|c|c|c|}
\hline No & 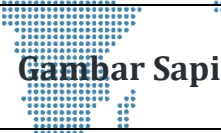 & $\begin{array}{c}\text { Panjang } \\
\text { Badan: } \\
\text { : }\end{array}$ & $\begin{array}{l}\text { Lingkar } \\
\text { dada }\end{array}$ & $\begin{array}{l}\text { Bobot sapi } \\
\text { sebenarnya }\end{array}$ & $\begin{array}{c}\text { Bobot sapi } \\
\text { Menggunakan } \\
\text { sistem }\end{array}$ & $\begin{array}{c}\text { Persentase } \\
\text { Kesalahan } \\
\text { absolute }\end{array}$ \\
\hline 7 & & $2,22 \mathrm{~m}$ & $2,30 \mathrm{~m}$ & $500 \mathrm{Kg}$ & $488 \mathrm{Kg}$ & $2,40 \%$ \\
\hline 8 & & $2,58 \mathrm{~m}$ & $2,94 \mathrm{~m}$ & $800 \mathrm{Kg}$ & $796 \mathrm{Kg}$ & $0,50 \%$ \\
\hline 9 & & $2,26 \mathrm{~m}$ & $2,30 \mathrm{~m}$ & $500 \mathrm{Kg}$ & $486 \mathrm{Kg}$ & $2,80 \%$ \\
\hline 10 & & $2,56 \mathrm{~m}$ & $2,74 \mathrm{~m}$ & $700 \mathrm{Kg}$ & $695 \mathrm{Kg}$ & $0,71 \%$ \\
\hline \multicolumn{6}{|c|}{ Rata-rata Error (MAPE) } & $1,52 \%$ \\
\hline
\end{tabular}

Pada tabel 1 telah diketahui hasil perhitungan akurasi dari 10 sapi menggunakan Mean Absolute Percentage Error (MAPE) dengan rata-rata error sebesar 1,52 \%. Dari hasil perhitungan diatas diketahui pula akurasi hasil penelitian dengan perhitungan sebagai berikut :

Akurasi $(\%)=100 \%-\operatorname{Error}(\%)$

Akurasi $(\%)=100 \%-1,52(\%)$

Akurasi $(\%)=98,48 \%$

\section{SIMPULAN}

Dari hasil penelitian dan pembahasan yang dibuat oleh penulis, maka dapat disimpulkan bahwa hasil dari perhitungan yang dibuat oleh Aplikasi Pengolahan Citra Penghitung Bobot Sapi menggunakan metode Titik Berat Berbabis Android berjalan dengan baik dengan hasil yang hampir akurat. Dengan adanya Sistem Aplikasi ini dalam perhitungan bobot sapi diharapkan dapat mempermudah para peternak dan penjual sapi karena bisa digunakan dengan hp android. 


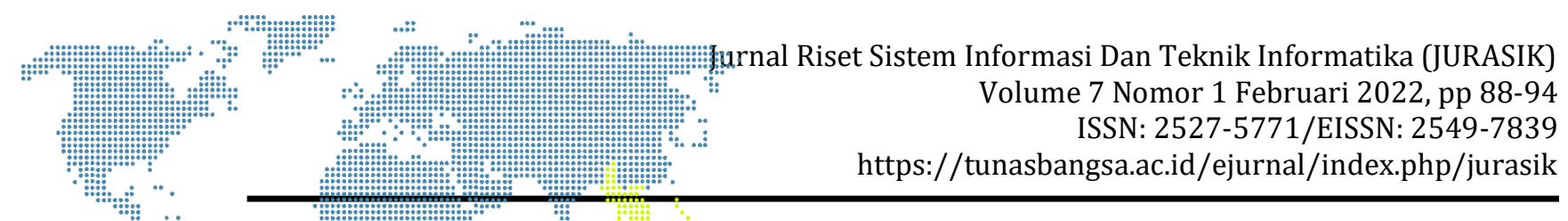

DAFTAR PUSTAKA

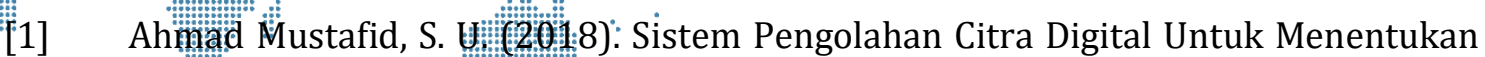
Bobot Sapi Menggunakàn Metode Tititk Berat. Jurnal Teknologi Informasi dan Ilmu Komputer, 677-686.

[2] Aris Riyanto, R. K. (2016). Aplikasi Pendugaan Berat Badan Sapi Dengan Memanfaatkan Kamera Pada Smartphone Berbasis Android. Jurnal Teknologi dan Sistem Informatika, 491-496.

[3] Erwin. (2020). Perancangan Sistem Pengolahan Citra Untuk Menentukan Bobot Kerbau. Jurnal Majalah Ilmiah Informasi dan Teknologi Ilmiah (INTI), 175-181.

[4] Pelitahijau, 30 januari 2017, Pengertian dan Rumus Titik Berat dalam Fisika, https://pelitahijau.blogspot.com/2017/01/pengertian-dan-rumus-titik-beratdalam.html, diakes pada 10 November 2021 pukul 18.10

[5] Puji Triono, M. (2015). APLIKASI PENGOLAHAN CITRA UNTUK MENDETEKSI FRAKTUR TULANG. JURNAL INFORMATIKA Vol. 9, No. 2, 1115-1123.

[6] Putri Ragil Nilamsari, D. I. (2017). Estimasi Bobot Karkas Sapi Pedaging Menggunakan Metode Fraktal dan. Seminar Nasional Pendidikan Biologi dan Saintek II, 364-372.

[7] Rany Zuriatna UtamiI, M. B. (2015). MENENTUKAN LUAS OBJEK CITRA DENGAN TEKNIK DETEKSI TEPI . ISSN 2086-9487, 11-17.

[8] Uyun, A. M. (2017). Segmentasi Citra Sapi Berbasis Deteksi Tepi Menggunakan Algoritma Canny Edge Detection. Jurnal Buana Informatika, 27-36. 